\title{
Biochemical diversity within the 'Mycoplasma mycoides cluster'
}

\author{
E. A. M. Abu-Groun, ${ }^{1} \dagger$ R. R. Taylor, ${ }^{1}$ H. Varsani, ${ }^{1}$ B. J. Wadher, ${ }^{1} \ddagger$ \\ R. H. Leach ${ }^{2}$ and R. J. Miles'
}

Author for correspondence: R. J. Miles. Tel: +44713334411. Fax: + 44713334500.

1 Division of Life Sciences, King's College, Campden Hill Road, London

W8 $7 \mathrm{AH}$, UK

2 National Collection of Type Cultures, London NW9 5HT, UK

\begin{abstract}
The metabolism of 51 strains within the 'Mycoplasma mycoides cluster' was investigated by measuring oxygen uptake following the addition of organic substrates to washed cell suspensions. There were extensive differences between strains in the range of substrates utilized, the relative rates of oxidation and the observed saturation constants for substrates, which ranged from a few $\mu M$ to several $\mathrm{mM}$. $M$. mycoides subsp. capri and $M$. mycoides subsp. mycoides LC (large colony) strains were diverse and could not be distinguished by substrate utilization patterns. However, there were consistent differences in the patterns of substrate utilization between other groups of the $\boldsymbol{M}$. mycoides cluster, suggesting that these patterns may be useful in identification. In particular, SC (small colony) strains of $M$. mycoides subsp. mycoides were distinguished by their inability to oxidize maltose, trehalose and (at low concentrations) mannose and glucosamine. Surprisingly, the type strain, M. F38, of Mycoplasma capricolum subsp. capripneumoniae and two further isolates differed from all other strains in that they did not oxidize glucose or other sugars. They did, however, oxidize pyruvate, lactate and 2-oxobutyrate at high rates. The marked metabolic differences between these strains and $M$. capricolum subsp. capricolum strains is in contrast to the genetic evidence that was used to support the designation of the $M$. F38 group as a subspecies of $M$. capricolum.
\end{abstract}

Keywords: Mycoplasma mycoides cluster, Mycoplasma capricolum, substrate oxidation patterns, mycoplasma identification

\section{INTRODUCTION}

The genus Mycoplasma currently contains more than 80 recognized species. These may be categorized according to whether they produce acid from glucose metabolism, ammonia from arginine hydrolysis, or both or neither of these reactions. A few additional, readily determined biochemical tests (Freundt \& Razin, 1984) may also be useful as a guide to identification; however, routine serological tests are always required to determine species or subspecies identity. Furthermore, the absence of

\footnotetext{
†Present address: College of Medical Laboratory Sciences, PO Box 10802, Khartoum, Sudan.

$\ddagger$ Present address: Department of Microbiology, Nagpur University, Nagpur 440010, India.

Abbreviations: d.o.t., dissolved oxygen tension; GICNAC, $\mathrm{N}$-acetylglucosamine; PEP:PTS, phosphoenolpyruvate: phosphotransferase; SC, small colony; LC, large colony.
}

specific serological reactivity with established species is currently the main criterion for recognition of new species (Anon., 1979).

The dependence upon serological tests for Mycoplasma characterization can lead to difficulties in the identification of new isolates if there are extensive serological crossreactions between species or subspecific groups. Such difficulties are particularly evident within the groups of strains referred to by Cottew et al. (1987) as the 'Mycoplasma mycoides cluster' (Cottew, 1979; Cottew et al., 1987; Nascimento et al., 1986; Salih et al., 1983). This cluster comprises six groups with the following original designations: $M$. mycoides subsp. capri; $M$. mycoides subsp. mycoides small colony (SC) strains; $M$. mycoides subsp. mycoides large colony (LC) strains; Bovine serogroup 7; $M$. capricolum; and the F38-like group. The latter two have now been designated separate subspecies of $M$. capricolum and named subsp. capricolum and capripneumoniae, respectively (Leach et al., 1993). All groups are pathogens and the 
principal hosts are cattle, goats or sheep. The SC strains of $M$. mycoides subsp. mycoides cause contagious bovine pleuropneumonia (CBPP), a disease of particular economic importance which is widespread in Africa, Asia and the Middle East, and a cause of concern in Europe following recent outbreaks in France, Portugal, Spain and Italy (ter Laak, 1992). The majority of SC strains have been isolated from cattle, but isolations have also been made from goats (see Cottew, 1979). The LC biotype of M. mycoides subsp. mycoides may also occur in both cattle and goats and unclassified subsp. mycoides strains have been reported in sheep (Okoh \& Ocholi, 1986; Cottew, 1979). M. mycoides subsp. capri, M. capricolum subsp. capricolum and $M$. capricolum subsp. capripneumoniae are mainly associated with goats, the latter being the causative agent of classical contagious caprine pleuropneumonia (CCPP; MacOwan \& Minette, 1977).

Despite clear cultural and other phenotypic differences, there is a particularly close serological relationship between the M. mycoides subsp. mycoides SC and LC strains and many of the dominant protein antigens are shared (Archer, 1979). Some of these are also shared by subsp. capri strains and analysis of cell proteins by gel electrophoresis suggests that LC strains of $M$. mycoides subsp. mycoides are more closely related to $M$. mycoides subsp. capri than to SC strains (Costas et al., 1987; Leach et al., 1989; Rodwell \& Rodwell, 1978). M. capricolum subspp. capricolum and capripneumoniae are also closely related on these grounds, as befits their subspecies classification. In addition, DNA-DNA hybridization was from 82 to $100 \%$ amongst subsp. capricolum strains, 87 to $100 \%$ amongst $M$. F38-related strains and 67 to $73 \%$ between members of the two groups under high-stringency conditions (Anon., 1991; Bonnet et al., 1993). These findings led to the designation of these two groups as subspecies within M. capricolum (Leach et al., 1993).

The development of easily determined biochemical testing procedures for mycoplasmas could help overcome the problem of serological cross-reaction and simplify current identification procedures. However, the development of such procedures is less well advanced than for other: bacterial groups. In particular, substrate utilization tests, of great value in the characterization of other bacteria, are little used for mycoplasmas, except those for glucose and arginine. The routine detection of substrate metabolism during mycoplasma growth is often not feasible because: of the low concentrations of organisms, and because of: difficulties in detecting the metabolism of specific substrates in the presence of the complex medium components needed to support mycoplasma growth which. provide a vast array of alternative substrates. In addition. the utilization of $\mathrm{di}$ - and polysaccharides of glucose cannot be determined in serum-containing medium, since they are rapidly hydrolysed by serum enzymes (Miles \& Lee, 1983).

The metabolism of specific substrates by cells suspended in an inorganic salts solution has been monitored using microcalorimetry for $M$. mycoides subsp. mycoides strain T1 (Miles et al., 1985), and by measuring changes in the dissolved oxygen tension of cell suspensions for $M$. mycoides subsp. capri strain PG3 (NCTC 10137; Miles \& Wadher, 1990). In this paper, we report the application of the latter technique to the determination of substrate utilization by 51 strains representing the six groups of the $M$. mycoides cluster. The substrates tested in this study included all those previously shown to be metabolized by M. mycoides subsp. mycoides strain $\mathrm{T} 1$ and other bovine, caprine and ovine mycoplasmas (Wadher et al., 1990), except that threonine and serine (utilized at low rates by strain T1) were excluded and 2-oxobutyrate, a likely intermediate in threonine metabolism (Rodwell, 1960), was included.

A major aim of this work was to determine whether patterns of substrate utilization could distinguish the members of the M. mycoides cluster. However, the technique also provides kinetic data allowing assessment of the likely significance of substrate metabolism at the concentrations found in vivo. Differences in substrate utilization patterns between isolates may be related to host or tissue specificity and thus aid understanding of pathogenicity.

\section{METHODS}

Organisms. The strains used are listed in Table 1. They were obtained as broth cultures or freeze-dried ampoules and upon receipt were subcultured in broth, dispensed in ampoules and stored in liquid nitrogen for further use. For brevity, $M$. capricolum subsp. capricolum and $M$. capricolum subsp. capripneumoniae (F38-type) will be referred to throughout this paper simply as 'subsp. capricolum' and 'subsp. capripneumoniae', respectively.

Media. All mycoplasmas except subsp. capripneumoniae strains were grown in a medium containing heat-inactivated pig serum, tryptose, yeast extract, glucose, glycerol and inorganic salts, as previously described (Wadher \& Miles, 1988). Subsp. capripneumoniae strains were grown in a medium containing proteose peptone, $15 \mathrm{~g} \mathrm{l}^{-1}$ (Oxoid); neutralized liver digest, $2.5 \mathrm{~g} \mathrm{l}^{-1}$ (Oxoid); yeast extract, $5 \mathrm{~g} \mathrm{l}^{-1}$ (Oxoid); $\mathrm{NaCl}, 5 \mathrm{gl}^{-1}$; glucose, $5 \mathrm{~g} \mathrm{l}^{-1}$; sodium pyruvate $5 \mathrm{~g} \mathrm{l}^{-1}$; fresh yeast extract (Freundt, 1983), $20 \mathrm{ml} \mathrm{l}^{-1}$; and heat-inactivated pig serum, $200 \mathrm{ml} \mathrm{l}^{-1}$ (Gibco). The $\mathrm{pH}$ value of both media was 7.6 .

Growth and preparation of cell suspensions. Broth medium was dispensed in $10 \mathrm{ml}$ quantities in plastic screw-capped testtubes (Sterilin) and inoculated with $0 \cdot 1 \mathrm{ml}$ of a liquid nitrogen stored culture. After $48 \mathrm{~h}$ incubation at $37^{\circ} \mathrm{C}, 0 \cdot 1 \mathrm{ml}$ quantities of these cultures were transferred to fresh medium and similarly incubated. Cells were then harvested by centrifugation at $14000 \mathrm{~g}$ for $4 \mathrm{~min}$ (MSE Microcentaur) and the cell pellets were washed and resuspended in a solution containing $18 \mathrm{~g} \mathrm{HEPES}^{-1}$ and $160 \mathrm{U}^{\text {catalase }} \mathrm{ml}^{-1}$ (Sigma) in one-quarter strength Ringer's solution (Oxoid). The $\mathrm{pH}$ of the suspending medium was 7.6 . The cell protein content of mycoplasma suspensions was determined by the Lowry method, and viable counts performed as described by Miles et al. (1985).

Substrate metabolism. Substrate oxidation was determined from changes in dissolved oxygen tension (d.o.t.) with an oxygen electrode system (Rank Brothers) linked to a chart recorder and calibrated with air-saturated water (Miles et al., 1991). Cell suspensions $(1 \mathrm{ml})$ containing $100-300 \mu \mathrm{g}$ cell protein and a viable count of $5 \times 10^{8}-2 \times 10^{9}$ c.f.u. were added 
Table 1. Mycoplasma strains used and their sources

\begin{tabular}{|c|c|}
\hline Strain designation* & $\begin{array}{c}\text { Country of } \\
\text { isolation }\end{array}$ \\
\hline \multicolumn{2}{|l|}{ Bovine serogroup 7} \\
\hline PG50 (NCTC 10133) & Australia \\
\hline L2917, QR1 & Australia $†$ \\
\hline \multicolumn{2}{|l|}{ M. capricolum subsp. capripneumoniae } \\
\hline $\mathrm{F}^{2} 8^{\mathrm{T}}$ (NCTC 10192), G183 & Kenyat \\
\hline G94/83, G1943/80 & Kenya $\neq$ \\
\hline \multicolumn{2}{|l|}{ M. capricolum subsp. capricolum } \\
\hline California kid ${ }^{\mathrm{T}}$ (NCTC 10154) & USA $†$ \\
\hline $607 / 79,4161 / 88$ & France $\int$ \\
\hline YP, YO, ZT & Australia \\
\hline PP goat & Turkey† \\
\hline \multicolumn{2}{|l|}{ M. mycoides subsp. capri } \\
\hline $\mathrm{PG}^{\mathrm{T}}$ (NCTC 10137) & Turkey \\
\hline N108 & Nigeriat \\
\hline YC, ZZ, 74.5907A, JM & Australia† \\
\hline Pendik, BQT & Turkeyt \\
\hline G108/A2 clone(a), G108/A2 clone(b) & Brazilt \\
\hline G105/A1, G169/Leite, G108/A3 & \\
\hline \multicolumn{2}{|l|}{ M. mycoides subsp. mycoides (LC) } \\
\hline Y-goat ${ }^{\mathrm{R}}, \mathrm{VRI}, 74 / 2488,81.636 .1 \mathrm{C}$ & Australia \\
\hline \multicolumn{2}{|l|}{ GE.6A.79E, KHI, 78/441, 11041} \\
\hline F30 & Kenya \\
\hline OJO1 & Nigeria† \\
\hline $\mathrm{COV} 2$ & Turkeyt \\
\hline GM12 & $\mathrm{USA} \dagger$ \\
\hline $977 / 79,400 / 79,755 / 80,221 / 82$ & France $\$$ \\
\hline $1645 / 82,1729 / 82,842 / 86$ & \\
\hline \multicolumn{2}{|l|}{ M. mycoides subsp. mycoides (SC) } \\
\hline \multicolumn{2}{|l|}{ PG1 $1^{\mathrm{T}}$ (NCTC 10114) } \\
\hline Gladysdale & Australia $†$ \\
\hline Oremit & Kenyat \\
\hline $\mathrm{T} 1$ & Kenyall \\
\hline KH3J & Sudant \\
\hline
\end{tabular}

* $\mathrm{T}$, Type strain; $\mathrm{R}$, reference strain for designated taxon.

† See Costas et al. (1987); Leach et al. (1989).

$\ddagger$ Culture provided by Professor F. R. Rurangirwa and Dr A. Kebor, Nairobi, Kenya.

$\int$ Culture provided by Mr Maurice Lambert, CNEVA, Laboratoire de Pathologie des Petits Ruminants, 06000 Nice, France.

\|Culture provided by Dr G. R. Smith, Institute of Zoology, Regent's Park, London, UK.

to the electrode vessel which was magnetically stirred and maintained at $37^{\circ} \mathrm{C}$. The air-saturated suspension (d.o.t. approximately $210 \mathrm{nmol} \mathrm{ml}^{-1}$ ) was then isolated from the air and a test substrate was added by microsyringe. Organic acids were added as their sodium salts. All experiments were repeated; the data shown are mean values of two or more replicate experiments.

Calculation of kinetic parameters of substrate utilization. In general, saturation constants $\left(K_{\mathrm{m}}\right.$ values) were estimated from recorder tracings of change in d.o.t. with time following addition of a low concentration of substrate (up to $50 \mu \mathrm{M}$ ). It was assumed that Michaelis kinetics were observed (Miles $e t$ al., $1985)$ and that the reduction in d.o.t. at any time $(t)$ after substrate addition was proportional to the substrate used. Thus, substrate concentration $(s)$ at time $t$ was (initial substrate concentration $) \times(a-b) / a$, where $a$ was the total reduction in d.o.t. following substrate addition and $b$ the reduction in d.o.t. at time $t$. The straight line of best fit was then drawn in plots of $1 /$ (rate of oxygen uptake) versus $1 /(s)$, and the intercept on the $1 / s$ axis (equal to $-1 / K_{m}$ ) determined. In those cases where the affinity for substrate was low (i.e. $K_{m}>50 \mu \mathrm{M}$ ), rates of oxygen uptake were determined at a number of different initial substrate concentrations.

\section{RESULTS}

\section{Effect of substrate concentration on rate of metabolism}

A representative curve showing the change in d.o.t. after the addition of metabolizable substrate to a mycoplasma cell suspension is given in Fig. 1. No oxygen uptake (reduction in d.o.t.) was observed in the absence of substrate.

All strains, except three subsp. capripneumoniae strains (F38, G1943/80, G94/83), oxidized glucose $(25 \mu \mathrm{M})$ at a high initial rate [oxygen uptake rate 40$200 \mathrm{nmol} \mathrm{O}{ }_{2} \min ^{-1}\left(\mathrm{mg}\right.$ cell protein $\left.{ }^{-1}\right)$, which was not increased by increasing glucose concentrations tenfold; total oxygen uptake [approximately $2 \mathrm{~mol}(\mathrm{~mol} \mathrm{glu}-$ cose $)^{-1}$ ] was consistent with the expected oxidation of added glucose to acetate plus $\mathrm{CO}_{2}$ (Rodwell \& Mitchell, 1979). $K_{\mathrm{m}}$ values for glucose oxidation were estimated to be $<5 \mu \mathrm{M}$ and similarly low $K_{\mathrm{m}}$ values were obtained for many mycoplasma-substrate combinations (as exemplified in the results for three individual strains shown in

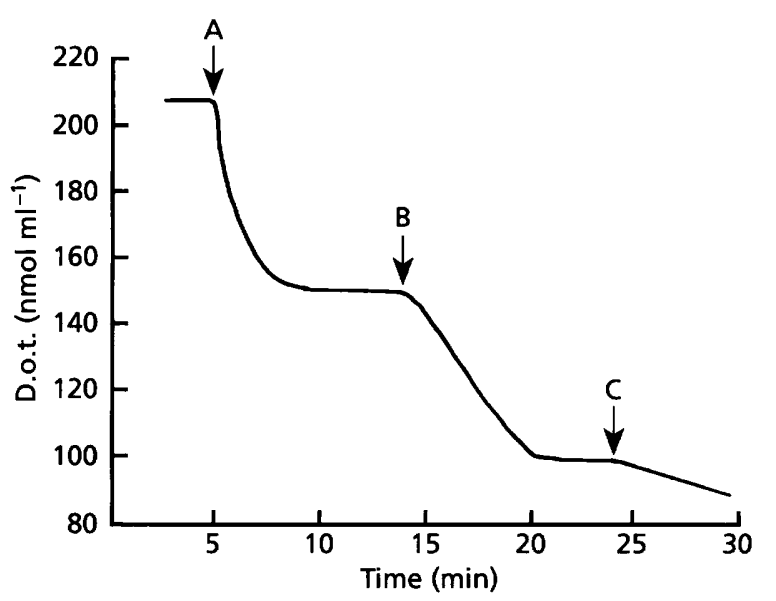

Fig. 1. Changes in d.o.t. following addition of oxidizable substrates to a cell suspension of $M$. capricolum strain PP goat. The substrates added were (A) glucose, (B) GICNAC and (C) glucosamine. All substrates were added to an initial concentration of $25 \mathrm{nmol} \mathrm{ml}^{-1}$. 
Table 2. Values of $K_{\mathrm{m}}$ for utilization of substrates by representative mycoplasma strains

\begin{tabular}{|c|c|c|c|}
\hline \multirow[t]{2}{*}{ Substrate } & \multicolumn{3}{|c|}{$K_{\mathrm{m}}$ value $(\mu \mathbf{M})$} \\
\hline & $\begin{array}{c}\text { M. mycoides } \\
\text { subsp. mycoides } \\
\text { PG1 }\end{array}$ & $\begin{array}{l}\text { M. mycoides } \\
\text { subsp. capri } \\
\text { PG3 }\end{array}$ & $\begin{array}{c}\text { M. capricolum subsp. } \\
\text { capripneumoniae } \\
\text { G94/83 }\end{array}$ \\
\hline Glucose & $3 \cdot 5$ & $4 \cdot 8$ & ND \\
\hline Maltose & ND & $1 \cdot 3$ & ND \\
\hline Trehalose & ND & $2 \cdot 0$ & ND \\
\hline GlcNAc & $1 \cdot 0$ & $1 \cdot 0$ & ND \\
\hline Glucosamine & 620 & 10 & ND \\
\hline Mannose & $9 \cdot 1 \mathrm{mM}$ & $2 \cdot 8$ & ND \\
\hline Fructose & $3 \cdot 9$ & $1 \cdot 7$ & ND \\
\hline Glycerol & 3.5 & $6 \cdot 6$ & ND \\
\hline Pyruvate & 6.0 & 18 & $5 \cdot 8$ \\
\hline Lactate & 260 & 630 & $4 \cdot 6$ \\
\hline 2-Oxobutyrate & $9 \cdot 3$ & $>1 \mathrm{mM}$ & $9 \cdot 7$ \\
\hline
\end{tabular}

ND, Metabolism not detected.
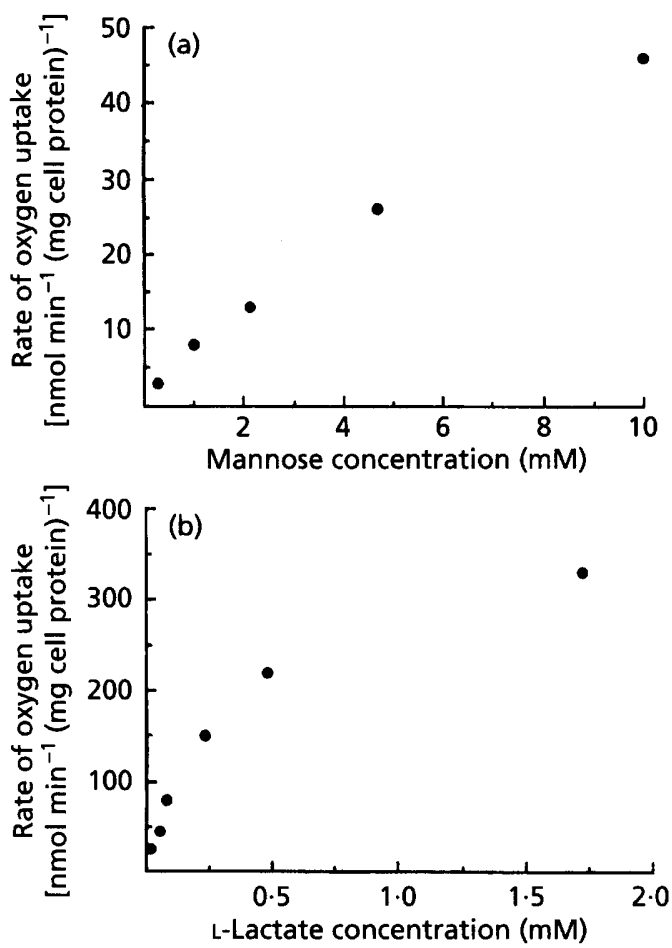

Fig. 2. Effect of (a) mannose and (b) L-lactate concentration on the rate of oxygen uptake by $M$. mycoides subsp. mycoides PG 1 (NCTC 10114). The rate of oxygen uptake by cell suspensions with glucose $(25 \mu \mathrm{M})$ was $70 \mathrm{nmol} \mathrm{m^{-1 }}(\mathrm{mg} \text { cell protein })^{-1}$.

Table 2). However, in some cases apparent $K_{\mathrm{m}}$ values were high (Table 2) and substrate metabolism was detectable only at relatively high substrate concentrations (e.g. mannose utilization by $M$. mycoides subsp. mycoides
PG1; Fig. 2a). Also, lactate oxidation was generally detectable at low concentrations, but the rate of oxidation incrased with increasing substrate concentration (e.g. $M$. mycoides subsp. mycoides PG1; Fig. 2b).

\section{Comparison of rates of substrate utilization by mycoplasmas}

To compare substrate utilization by different mycoplasma strains, rates of oxidation were initially determined at concentrations of $12 \mu \mathrm{M}$ for disaccharides, $25 \mu \mathrm{M}$ for monosaccharides and amino sugars, and $50 \mu \mathrm{M}$ for organic acids. These low initial substrate concentrations were chosen so that, after oxygen uptake had ceased due to exhaustion of rapidly metabolized substrate, further (different) substrate could be added (Fig. 1). Substrate concentration was varied in the above manner so that total oxygen uptake would be similar for each substrate and sufficient to allow accurate determination of the initial uptake rate. Where substrate utilization was not detected at these initial concentrations of $12-50 \mu \mathrm{M}$, substrate concentration was increased tenfold. Rates of substrate utilization are generally compared in terms of the rate of oxygen uptake, expressed as a percentage of the rate with glucose $(25 \mu \mathrm{M}$; Tables $3-5)$. The rate for glucose was determined prior to the addition of other substrates (Fig. 1) and after utilization was complete. In replicate experiments, rates of substrate utilization were consistent.

M. mycoides strains. The five $M$. mycoides subsp. mycoides SC strains appeared similar in the pattern and rates of substrate utilization (Table 3). All strains were unable to metabolize the disaccharides maltose and trehalose, but oxidized $\mathrm{N}$-acetylglucosamine (GlcNAc), glycerol and 2oxobutyrate at high rates. The Gladysdale strain oxidized pyruvate and lactate at rates approximately two- to fourfold higher than the other strains. In contrast, the 19 
Table 3. Rate of substrate utilization by $M$. mycoides subsp. mycoides SC, $M$. capricolum subsp. capricolum and Bovine serogroup 7 strains

Rates determined at $12 \mu \mathrm{M}$ for disaccharide sugars, $25 \mu \mathrm{M}$ for monosaccharide sugars and $50 \mu \mathrm{M}$ for other substrates. Rates of $\mathrm{O}_{2}$ uptake are expressed as a percentage of the initial rate for glucose; $\mathrm{O}_{2}$ uptake rates for glucose were between 15 and $30 \mathrm{nmol} \mathrm{min}^{-1} \mathrm{ml}^{-1}$. + , Oxygen uptake only detectable when substrate concentration increased tenfold; ND, oxygen uptake not detectable even when substrate concentration increased tenfold.

\begin{tabular}{|c|c|c|c|c|c|c|c|}
\hline \multirow[t]{3}{*}{ Substrate } & \multicolumn{7}{|c|}{ Initial rate of $\mathrm{O}_{2}$ uptake (percentage of initial rate for $25 \mu \mathrm{M}$ glucose) } \\
\hline & \multirow{2}{*}{$\begin{array}{l}\text { M. mycoides } \\
\text { subsp. } \\
\text { mycoides SC } \\
\text { (5 strains) }\end{array}$} & \multicolumn{3}{|c|}{ M. capricolum subsp. capricolum strains } & \multicolumn{3}{|c|}{ Bovine serogroup 7} \\
\hline & & $\begin{array}{c}\text { California } \\
\text { kid }\end{array}$ & $4161 / 88$ & $\begin{array}{c}\text { Others } \\
\text { (5 strains) }\end{array}$ & PG50 & QR1 & L2917 \\
\hline Maltose & ND & 28 & 34 & $15-26^{*}$ & 46 & 43 & 18 \\
\hline Trehalose & ND & $\mathrm{ND}$ & ND & ND & 120 & 57 & 63 \\
\hline GlcNAc & $48-72$ & 63 & 12 & $19-38+$ & 52 & 13 & ND \\
\hline Glucosamine & + & 6 & + & $48 \ddagger$ & + & + & 11 \\
\hline Mannose & + & + & + & + & + & + & + \\
\hline Fructose & $13-30$ & 20 & 42 & $13-33$ & 30 & 32 & 9 \\
\hline Glycerol & $75-178$ & ND & ND & $61-205$ & 130 & 84 & 270 \\
\hline Pyruvate & $31-121 \S$ & 9 & 30 & 5-22 & 48 & 25 & 25 \\
\hline Lactate & $11-48 \|$ & 26 & 12 & $5-349$ & 43 & 61 & 17 \\
\hline 2-Oxobutyrate & $32-65$ & + & ND & + & ND & 18 & 21 \\
\hline
\end{tabular}

* Except PP goat (rate 4).

† Except $607 / 79(+)$.

‡Excepr YP (ND), YO (ND).

Gladysdale strain 121 , other strains $<76$.

\| Gladysdale strain 48, other strains $<29$.

g Except YP (153), YO (117).

Table 4. Rate of substrate utilization by $M$. mycoides subsp. mycoides LC strains

See Table 3 for substrate concentrations used and key to symbols.

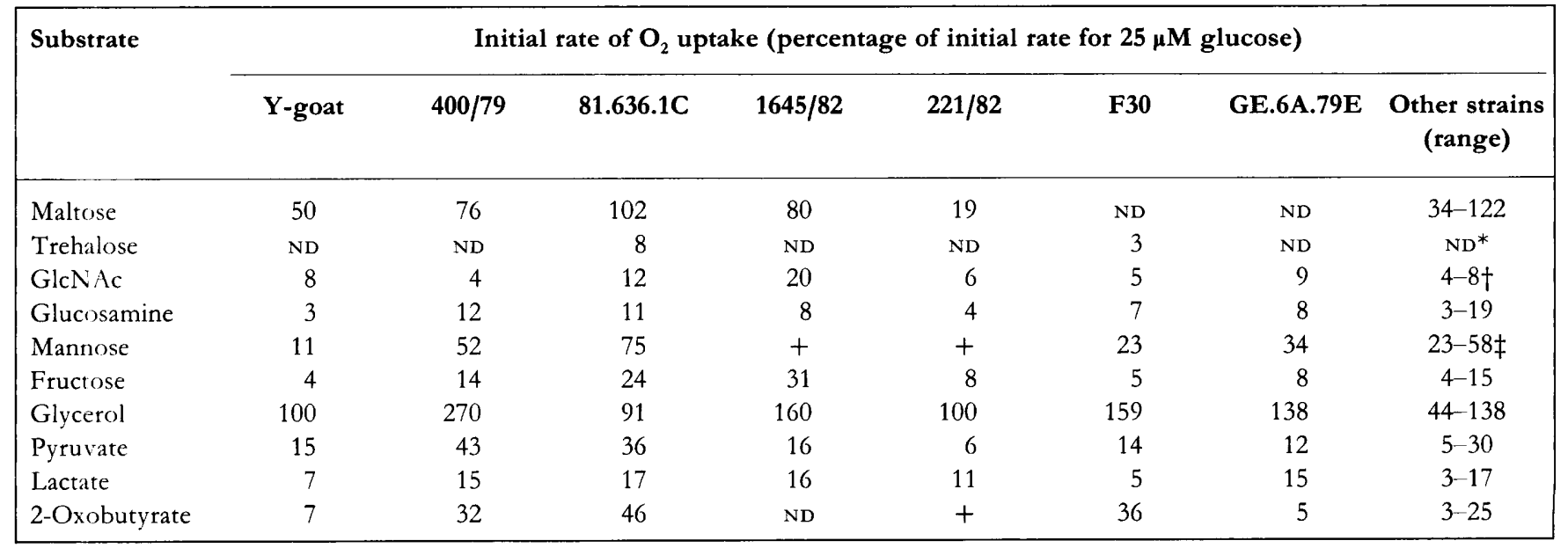

* Except 74/2488 (rate +), VRI (+), 977/79 (8) and 842/86 (8).

†Except OJO 1 (ND), KHI (ND), 78/441 (+), $11041(+), 977 / 79(+), 755 / 80(+)$ and 842/86(+).

$\ddagger$ Except OJO 1 (3). 
Table 5. Rate of substrate utilization by $M$. mycoides subsp. capri strains

See Table 3 for substrate concentrations used and key to symbols.

\begin{tabular}{|c|c|c|c|c|c|c|c|c|}
\hline \multirow[t]{2}{*}{ Substrate } & \multicolumn{8}{|c|}{ Initial rate of $\mathrm{O}_{2}$ uptake (percentage of initial rate for $25 \mu \mathrm{M}$ glucose) } \\
\hline & $\begin{array}{c}\text { NCTC } \\
10137\end{array}$ & BQT & Pendik & $\mathbf{Z Z}$ & $\mathbf{J M}$ & $\begin{array}{c}\text { Isolates } \\
\text { from } \\
\text { Brazil* }\end{array}$ & $\begin{array}{l}\text { G169/ } \\
\text { Leite }\end{array}$ & $\begin{array}{l}\text { Other } \\
\text { strains } \\
\text { (range) }\end{array}$ \\
\hline Maltose & 35 & 47 & 42 & 35 & 43 & $49-71$ & ND & $48-66$ \\
\hline Trehalose & 72 & 41 & ND & ND & ND & $6-10$ & 5 & ND† \\
\hline GlcNAc & 15 & 5 & + & ND & ND & + & 5 & + \\
\hline Glucosamine & 35 & 7 & 9 & 13 & 4 & $7-14$ & 6 & $7-11$ \\
\hline Mannose & 50 & 70 & 68 & 47 & 2 & $34-48$ & 27 & $33-95$ \\
\hline Fructose & 18 & 28 & 14 & 12 & 5 & 5-14 & 10 & $10-15$ \\
\hline Glycerol & 230 & 250 & 106 & 77 & 88 & $76-126$ & 67 & $80-220$ \\
\hline Pyruvate & 20 & 27 & + & ND & 10 & $5-17$ & 26 & $19-35$ \\
\hline Lactate & 12 & 20 & 2 & 3 & 7 & $7-11$ & 15 & $7-16$ \\
\hline 2-Oxobutyrate & + & 78 & + & 5 & 16 & $4-15$ & 31 & $30-40$ \\
\hline
\end{tabular}

*G105/A1, G108/A2a, G108/A2b, G108/A3.

† Except YC (rate +).

LC strains appeared metabolically diverse. Table 4 shows rates of substrate utilization for the reference strain ( $\mathrm{Y}$ goat), a number of strains with individually distinctive characteristics and the remaining more homogeneous strains. The reference strain oxidized all substrates tested except trehalose; it oxidized mannose and glucosamine at relatively low rates but appeared otherwise typical of the group. Strains $1645 / 82$ and $221 / 82$ had little or no activity towards mannose and 2-oxobutyrate, and two strains (F30 and GE.6A.79E) failed to oxidize maltose. Strains $81.63 .61 \mathrm{C}$ and $400 / 79$ oxidized the organic acids (lactate, pyruvate and 2-oxobutyrate) at particularly high rates; in contrast, for a number of strains (OJO 1, 78/441, 11041, VRI, COV2), the maximum rate of oxygen uptake in the presence of organic acids $(50 \mu \mathrm{M})$ was $<10 \%$ of the rate with glucose.

The M. mycoides subsp. capri strains were also diverse (Table 5), although four of the five Brazilian strains gave very similar patterns. Strains differed particularly in their abilities to oxidize trehalose, GlcNAc and 2-oxobutyrate. In addition, two strains (Pendik and ZZ) oxidized organic acids at low rates and the Brazilian strain G169/Leite did not metabolize maltose although this substrate was metabolized by all other subsp. capri strains at high rates.

Bovine serogroup 7 strains. The Bovine serogroup 7 strains (Table 3) were distinguished from strains of the three M. mycoides groups (Tables 3-5) by their high rate of trehalose metabolism coupled with their inability to oxidize mannose and glucosamine at low concentrations $(<50 \mu \mathrm{M})$. However, they varied in their ability to metabolize GlcNAc and 2-oxobutyrate.

Subspp. capricolum and capripneumoniae strains. All subsp. capricolum strains metabolized maltose and GlcNAc
(Table 3). Mannose and (except for one strain) 2oxobutyrate were also oxidized, but only in the presence of high substrate concentrations. Strains YP and YO were distinguished by their high rate of lactate $(50 \mu \mathrm{M})$ oxidation, and strains California kid and $4161 / 88$ by their inability to oxidize glycerol; glycerol was oxidized at high rates by all other strains.

The pattern of substrate oxidation by the subsp. capripneumoniae type strain (F38) was in marked contrast to that of $M$. mycoides, Bovine serogroup 7 and subsp. capricolum strains. Washed cell suspensions did not oxidize glucose, maltose or glycerol. However, pyruvate, lactate, 2-oxobutyrate and ethanol $(10 \mathrm{mM})$ were rapidly metabolized (Table 6). A similar pattern of substrate oxidation to that of F38 was observed for strains G1943/80 and G94/83, though strain G183 oxidized glucose and glycerol and, at much lower rates, pyruvate and lactate. None of the other substrates tested were metabolized by strain G183, except maltose, which appeared to stimulate $\mathrm{O}_{2}$ uptake minimally in some experiments (up to a value of $5 \%$ of the corresponding rate for glucose). However, this may reflect the relative difficulty in obtaining metabolically active cell suspensions of this organism which grew slowly and gave a relatively low cell yield. The type strain F38 also grew poorly in comparison with strains G1943/ 80 and G94/83.

Oxidation of ethanol (10 and $100 \mathrm{mM}$ ), observed in those subsp. capripneumoniae strains unable to oxidize glucose, was not detected in strain G183, nor in the subsp. capricolum strains listed in Table 1 , nor in strains representing the other four groups of the M. mycoides cluster.

Patterns of substrate utilization amongst the six groups of the $M$. mycoides cluster are summarized in Table 7. Patterns 
Table 6. Rate of substrate utilization by $M$. capricolum subsp. capripneumoniae strains

\begin{tabular}{|lcccc|}
\hline \multirow{2}{*}{ Substrate } & \multicolumn{4}{c|}{ Initial rate of $\mathbf{O}_{2}$ uptake (nmol min $^{\mathbf{- 1}}$ per 10 } \\
& NCTC $\mathbf{~}$ cells) \\
\cline { 2 - 5 } & ND & G1943/80 & G94/83 & G183 \\
\hline Glucose $(25 \mu \mathrm{M})$ & ND & ND & ND & $3 \cdot 0$ \\
Glycerol $(50 \mu \mathrm{M})$ & $8 \cdot 9$ & ND & ND & $3 \cdot 3$ \\
Pyruvate $(50 \mu \mathrm{M})$ & $8 \cdot 0$ & 20 & 16 & $0 \cdot 1$ \\
Lactate $(50 \mu \mathrm{M})$ & $9 \cdot 3$ & 17 & $7 \cdot 4$ & $0 \cdot 5$ \\
2-Oxobutyrate $(50 \mu \mathrm{M})$ & $2 \cdot 9$ & 19 & 14 & ND \\
Ethanol $(10 \mathrm{mM})$ & 15 & $2 \cdot 7$ & ND \\
\hline
\end{tabular}

ND, Not detected at the concentrations stated or ten times these concentrations.

Table 7. Patterns of substrate utilization amongst the constituent groups of the ' $M$. mycoides cluster'

The Table shows the number of strains able to use each substrate at low concentration $(12-50 \mu \mathrm{M}$, see text) and, in parentheses, at high concentration (up to $500 \mu \mathrm{M}$ ), if this increased the number of positive strains.

\begin{tabular}{|c|c|c|c|c|c|c|c|}
\hline Substrate & \multicolumn{3}{|c|}{ M. mycoides subsp. mycoides } & \multicolumn{3}{|c|}{ M. capricolum } & \multirow{4}{*}{$\begin{array}{c}\text { Bovine } \\
\text { serogroup } 7 \\
3\end{array}$} \\
\hline \multirow{3}{*}{$\begin{array}{l}\text { No. of } \\
\text { strains } \\
\text { tested... }\end{array}$} & \multirow[t]{2}{*}{ SC } & \multirow[t]{2}{*}{ LC } & \multirow[t]{2}{*}{ subsp. capri } & \multirow{2}{*}{$\begin{array}{c}\text { subsp. } \\
\text { capricolum }\end{array}$} & \multicolumn{2}{|c|}{ subsp. capripneumoniae } & \\
\hline & & & & & G183 & others & \\
\hline & 5 & 19 & 13 & 7 & 1 & 3 & \\
\hline Glucose & 5 & 19 & 13 & 7 & 1 & 0 & 3 \\
\hline Maltose & 0 & 17 & 12 & 7 & 1 & 0 & 3 \\
\hline Trehalose & 0 & $4(6)$ & $7(8)$ & 0 & 0 & NT & 3 \\
\hline GlcNic & 5 & $12(17)$ & $3(11)$ & $6(7)$ & 0 & NT & 2 \\
\hline Glucosamine & $0(5)$ & 19 & 13 & $4(5)$ & 0 & NT & $1(3)$ \\
\hline Mannose & $0(5)$ & $17(19)$ & 13 & $0(7)$ & 0 & NT & $0(3)$ \\
\hline Fructose & 5 & 19 & 13 & 7 & 0 & NT & 3 \\
\hline Glycerol & 5 & 19 & 13 & 5 & 1 & 0 & 3 \\
\hline Pyruvate & 5 & 19 & $11(12)$ & 7 & 1 & 3 & 3 \\
\hline Lactate & 5 & 19 & 13 & 7 & 1 & 3 & 3 \\
\hline 2-Oxobutyrate & 5 & $17(18)$ & $11(13)$ & $0(6)$ & 0 & 3 & 2 \\
\hline
\end{tabular}

NT, Not tested.

varied within all groups, except the SC group of $M$. mycoides subsp. mycoides. However, in general, there were consistent differences in patterns between groups.

\section{DISCUSSION}

The strains of the M. mycoides cluster varied both in their ability to oxidize the test substrates and in the affinity with which particular substrates were utilized (Table 2). Similarly, in a microcalorimetric study (Miles et al., 1985), the $K_{\mathrm{m}}$ values for glucose, glycerol, fructose and GlcNAc metabolism by $M$. mycoides subsp. mycoides strain T1 were $<5 \mu \mathrm{M}$, whereas the values for glucosamine and mannose were $130 \mu \mathrm{M}$ and $1.3 \mathrm{mM}$ respectively. Such differences in $K_{\mathrm{m}}$ values are important, as substrates with high $K_{\mathrm{m}}$ values may not be present in sufficient concentrations in vivo to be utilized at significant rates. Furthermore, where $K_{\mathrm{m}}$ values for substrates are high, mycoplasma strains may not be specifically adapted to their utilization. Thus, it appears that there are no mannose- or glucosaminespecific transport components in $M$. mycoides subsp. mycoides strain T1, and the inability of glucose-negative transport mutants [probably lacking glucose specific Enzyme IIB of the phosphoenolpyruvate:phosphotransferase (PEP:PTS) uptake system; Lee et al., 1986] to metabolize these substrates suggests that their entry into cells depends on glucose-specific component(s). In this study, all the glucose-oxidizing strains (Tables 3-5) in which mannose or glucosamine metabolism was not detectable at $25 \mu \mathrm{M}$ did use these sugars when the concentration was increased. Thus, it may be generally the case within the $M$. mycoides cluster that the glucose-specific component of the PEP:PTS system enables transport of glucosamine and mannose provided they are present at high concentrations. However, in some strains, specific transport components for mannose and/or glucosamine 
may additionally be present. For example, in the $M$. mycoides subsp. capri type strain, PG3, the $K_{\mathrm{m}}$ value for mannose utilization was $3 \mu \mathrm{M}$ and the rate of mannose oxidation was not reduced in glucose-negative transport mutants (R. R. Taylor \& R. J. Miles, unpublished). In comparisons of strains, therefore, the presence or absence of metabolism may not be as significant as the ability to metabolize low concentrations of substrate.

The ability to use specific substrates would not appear to be lost during in vitro cultivation in their absence. For example, maltose was metabolized by nearly all $M$. mycoides subsp. capri and LC strains although this substrate is not found in the serum-based media used for subculturing mycoplasmas (Miles \& Lee, 1983). Thus, since the catabolic activities and distribution of mycoplasmas are restricted, differences in patterns of substrate utilization within the $M$. mycoides cluster may reflect variations in tissue specificity and/or in host physiology. All glucoseoxidizing strains also oxidized fructose $(25 \mu \mathrm{M})$, although oxygen uptake rates varied between 4 and $42 \%$ of the rate for glucose. The ability to utilize GlcNAc $(25 \mu \mathrm{M})$ at high rates was particularly associated with SC strains (Tables 3--5) whereas oxidation of mannose $(25 \mu \mathrm{M})$ at high rates was characteristic of $M$. mycoides subsp. capri strains and the majority of the LC strains. The ability to use GlcNAc and mannose is of particular interest since, although they are major constituents of mammalian glycoconjugates, they normally occur in body fluids as free sugars only at very low concentrations. However, host-derived $N$ acetylglucosaminidase and mannoside activities (principally from lysosomes) may be released into cell surroundings following cellular damage.

The ability to utilize the disaccharides maltose and trehalose is also of interest. These sugars are rapidly hydrolysed in serum (Miles \& Lee, 1983) and in vivo would not be available at sites accessible to serum enzymes. The ability of several Mycoplasma strains to oxidize trehalose also appears anomalous. This substrate does not appear to be present in mammalian tissues. It is possible that trehalose might be transported by a disaccharide uptake system, for which maltose is the principal substrate. However, a number of Mycoplasma mycoides subsp. capri strains (Table 5) oxidized trehalose $(12 \mu \mathrm{M})$ at high rates, suggesting the presence of a specific trehalose uptake system. Also, strain G169/Leite oxidized trehalose but not maltose.

All strains oxidized pyruvate $(50 \mu \mathrm{M})$ and/or lactate $(50 \mu \mathrm{M})$. These substrates apparently require a common component for transport in $M$. mycoides subsp. mycoides strain T1 (Lee et al., 1986), and with the Gladysdale SC strain both substrates $(50 \mu \mathrm{M})$ stimulated high oxygen uptake rates (Table 3). In contrast, uptake rates with the Pendik and ZZ strains of subsp. capri were low $(<3 \%$ of the rate for glucose). The significance of these differences is unclear. Pyruvate may be used as an energy source for the growth of M. mycoides subsp. capri (Miles et al., 1988) and the concentration of lactate and pyruvate in body fluids is sufficiently high (e.g. 0.5 and $0.05 \mathrm{mM}$ respectively in bovine serum; Altman \& Dittmer, 1974) to suggest that many strains are adapted to utilize these substrates in vivo. The ability to oxidize lactate at high rates (Fig. 2b) has also been proposed as a pathogenicity factor in, for example, Neisseria gonorrboeae (Britigan et al., 1988), reducing the $\mathrm{O}_{2}$ concentration and thus limiting the ability of neutrophils to generate reactive oxygen intermediates. 2-Oxobutyrate, an intermediate in threonine degradation (Rodwell, 1960), was oxidized at a high rate by all SC strains, whereas amongst the other groups this ability varied. The structural similarity between 2-oxobutyrate and pyruvate suggests that they might be substrates for the same uptake system. However, there was little correlation between the rates of pyruvate and 2oxobutyrate oxidation in individual strains.

Nearly all strains oxidized glycerol at high rates. In $M$. mycoides, glycerol is metabolized via an $\mathrm{L}$ - $\alpha$-glycerophosphate oxidase in a reaction which yields $1 \mathrm{~mol} \mathrm{H}_{2} \mathrm{O}_{2}$ (mol glycerol) ${ }^{-1}$. The quantity of $\mathrm{H}_{2} \mathrm{O}_{2}$ produced during glycerol oxidation is much greater than during oxidation of sugars or lactate (Miles et al., 1991). This may be of significance in vivo, since $\mathrm{H}_{2} \mathrm{O}_{2}$ production is potentially important in mycoplasma pathogenicity (Tryon \& Baseman, 1992). Glycerol oxidation might also be useful as a strain marker in epidemiological studies of subsp. capricolum, in which group it was oxidized by only four out of six strains.

A principal reason for determining patterns of substrate utilization in the $M$. mycoides cluster is their potential application to the identification of new isolates, using either the simple and rapid d.o.t. procedure described here, or alternative methods. The type strains of a range of fermentative bovine, caprine and ovine mycoplasma species have previously been shown to utilize distinct combinations of substrates (Wadher et al., 1990). However, in this study, biochemical diversity within the groups of the $M$. mycoides cluster was evident and some $M$. mycoides subsp. capri strains gave patterns of substrate utilization which were not readily distinguishable from those of $M$. mycoides subsp. mycoides LC strains. The similarity of PAGE protein patterns between LC and capri strains has previously been noted (Costas et al., 1987; Leach et al., 1989; Rodwell \& Rodwell, 1978). However, in general, there were consistent differences (Table 7) in the patterns of substrate utilization between the various groups of the $M$. mycoides cluster. In particular, SC strains of $M$. mycoides were distinguished by their inability to oxidize maltose, trehalose and (at low concentrations) mannose and glucosamine. Such differences are of potential value in identification, though the observed biochemical diversity within groups may necessitate testing further strains, particularly Bovine serogroup 7 strains, of which only three were included in this study. It is also possible that, in some cases, the apparent biochemical diversity between isolates assigned to species or subgroups may mirror the difficulty in the serological typing of strains. For example, the Brazilian isolates of $M$. mycoides subsp. capri included strain G169/Leite which did not oxidize maltose and thus differed from all other capri strains. A serological difference has also been noted, however, in indirect immunofluorescence tests (Leach $e t$ al., 1989), in which antiserum to M. mycoides subsp. capri 
(strain PG3) had a low titre (10) for G169/Leite, but a high titre $(100-400)$ for the other Brazilian strains. Similarly, antiserum prepared against the Gladysdale SC strain of M. mycoides subsp. mycoides had a high antibody titre ( $>1000$ ) against the two M. mycoides LC strains (F30 and GE.6A.79E) that, like all SC strains, failed to ferment maltose.

Surprisingly, the type strain F38 and two further subsp. capripneumoniae isolates (G1943/80 and G94/83) differed from all other strains in the study in that they did not oxidize glucose or other sugars. They did, however, oxidize pyruvate, lactate, 2-oxobutyrate and ethanol at high rates (Table 6 ). This pattern of substrate utilization is similar to that of $M$. agalactiae, M. bovigenitalium, M. bovis and M. californicum (Wadher et al., 1990). The subsp. capripneumoniae strains also oxidized ethanol; the likely end-product of its metabolism is acetate, and since oxidation presumably occurs via $\mathrm{NAD}^{+}$reduction with no energy conservation, the role of alcohol dehydrogenase activity is unclear.

Since the subsp. capripneumoniae strains do not oxidize sugars, they presumably lack both a PEP:PTS system and much of the Embden-Meyerhof pathway. The marked metabolic differences between these strains and subsp. capricolum strains is in contrast to the genetic and other evidence (Anon., 1991; Bonnet et al., 1993) used in proposing the $M$. F38 group as a subspecies of $M$. capricolum (Leach et al., 1993). However, Salih et al. (1983) have also shown, by electrophoretic analysis of a number of key enzyme activities, that F38-like strains differ considerably from those of subsp. capricolum and other members of the $M$. mycoides cluster. A single subsp. capripneumoniae isolate (G183) did oxidize glucose and glycerol but, unlike all subsp. capricolum strains, it did not oxidize GlcNAc and maltose was oxidized only at a low rate.

\section{ACKNOWLEDGEMENTS}

Technical assistance from $\mathrm{Mr} \mathrm{P}$. Rice, financial support from the Wellcome Trust, and the awards of an SERC studentship to R.R.T. and a King Faisal Foundation scholarship to E. A.M. A-G. are gratefully acknowledged.

\section{REFERENCES}

Altman, P. L. \& Dittmer, D. S. (1974). Biology Data Book, vol. 3, 2nd edn, p. 1963. Bethesda, MD: Federation of American Societies for Experimental Biology.

Anon. (1979). International Committee on Systematic Bacteriology. Subcommittee on the Taxonomy of Mollicutes. Proposal of minimal standards for descriptions of new species of the class Mollicutes. Int J Syst Bacteriol 29, 172-180.

Anon. (1991). International Committee on Systematic Bacteriology. Subcommittee on the Taxonomy of Mollicutes, Minute 11. Int $J$ Syst Bacteriol 41, 333-336.

Archer, D. B. (1979). Immunoprecipitation of Triton X-100solubilized Mycoplasma mycoides proteins. J Gen Microbiol 115, 111-116.

Bonnet, F., Saillard, C., Bové, J. M., Leach, R. H., Rose, D. L., Cottew, G. S. \& Tully, J. G. (1993). DNA relatedness between field isolates of Mycoplasma F38 group, the agent of contagious caprine pleuropneumonia, and strains of Mycoplasma capricolum. Int J Syst Bacteriol 43, 597-602.

Britigan, B. E., Klapper, D., Svendsen, T. \& Cohen, M. S. (1988). Phagocyte-derived lactate stimulates oxygen consumption by Neisseria gonorrboeae. J Clin Invest 81, 318-324.

Costas, M., Leach, R. H. \& Mitchelmore, D. L. (1987). Numerical analysis of PAGE protein patterns and the taxonomic relationships within the 'Mycoplasma mycoides cluster'. J Gen Microbiol 133, 3319-3329.

Cottew, G. S. (1979). Caprine-ovine mycoplasmas. In The Mycoplasmas, vol. 2, pp. 103-132. Edited by J. G. Tully \& R. F. Whitcomb. London: Academic Press.

Cottew, G. S., Breard, A., Da Massa, A. J., Ernø, H., Leach, R. H., Lefevre, P. C., Rodwell, A. W. \& Smith, G. R. (1987). Taxonomy of the Mycoplasma mycoides cluster. Isr J Med Sci 23, 632-635.

Freundt, E. A. (1983). Culture media for classic mycoplasmas. Methods Mycoplasmol 1, 127-135.

Freundt, E. A. \& Razin, S. (1984). Genus 1. Mycoplasma. In Bergey's Manual of Systematic Bacteriology, vol. 1, pp. 742-770. Edited by N. R. Kreig \& J. G. Holt. Baltimore: Williams \& Wilkins.

ter Laak, E. A. (1992). Contagious bovine pleuropneumonia: a review. Vet Q 14, 104-110.

Leach, R. H., Costas, M. \& Mitchelmore, D. L. (1989). Relationship between Mycoplasma mycoides subsp. mycoides ('large-colony' strains) and Mycoplasma mycoides subsp. capri, as indicated by numerical analysis of one-dimensional SDS-PAGE protein patterns. $J$ Gen Microbiol 135, 2993-3000.

Leach, R. H., Ernø, H. \& MacOwan, K. J. (1993). Proposal for designation of F38-type caprine mycoplasmas as Mycoplasma capricolum subsp. capripneumoniae subsp. nov. and consequent obligatory relegation of strains currently classified as $M$. capricolum (Tully, Barile, Edward, Theodore \& Ernø, 1974) to M. capricolum subsp. capricolum subsp. nov. Int J Syst Bacteriol 43, 603-605.

Lee, D. H., Miles, R. J. \& Beezer, A. E. (1986). Isolation and microcalorimetric characterisation of glucose-negative and pyruvate-negative mutants of Mycoplasma mycoides subsp. mycoides. FEMS Microbiol Lett 34, 283-286.

MacOwan, K. J. \& Minette, J. E. (1977). The role of mycoplasma F38 in contagious caprine pleuropneumonia (CCPP) in Kenya. Vet Rec 101, 380-381.

Miles, R. J. \& Lee, D. H. (1983). Carbohydrate utilisation by Mycoplasma mycoides subsp. mycoides strain T1 in a medium without serum. Microbios Lett 24, 129-133.

Miles, R. J. \& Wadher, B. J. (1990). Kinetics and pattern of substrate utilisation by Mycoplasma spp. Zentralbl Bakteriol Suppl 20, 675-677.

Miles, R. J., Beezer, A. E. \& Lee, D. H. (1985). Kinetics of utilization of organic substrates by Mycoplasma mycoides subsp. mycoides in a salts solution: a flow-microcalorimetric study. J Gen Microbiol 131, 1845-1852.

Miles, R. J., Wadher, B. J., Henderson, C. L. \& Mohan, K. (1988). Increased yields of Mycoplasma spp. in the presence of pyruvate. Lett Appl Microbiol 7, 149-151.

Miles, R. J., Taylor, R. R. \& Varsani, H. (1991). Oxygen uptake and $\mathrm{H}_{2} \mathrm{O}_{2}$ production by fermentative Mycoplasma spp. J Med Microbiol 34, 219-223.

Nascimento, E. R., Nascimento, M. Da G. F., Freundt, E. A. \& Anderson, H. (1986). Isolation of Mycoplasma mycoides from outbreaks of caprine mycoplasmosis in Brazil. Br Vet $J$ 142, 246-257.

Okoh, A. E. J. \& Ocholi, R. A. (1986). Disease associated with 
Mycoplasma mycoides subspecies mycoides in sheep in Nigeria. Vet Rec 118, 212.

Rodwell, A. W. (1960). Nutrition and metabolism of Mycoplasma mycoides var. mycoides. Ann NY Acad Sci 79, 499-507.

Rodwell, A. W. \& Mitchell, A. (1979). Nutrition, growth and reproduction. In The Mycoplasmas, vol. 1, pp. 103-139. Edited by M. F. Barile \& S. Razin. New York: Academic Press.

Rodwell, A. W. \& Rodwell, E. S. (1978). Relationships between strains of Mycoplasma mycoides subspp. mycoides and capri studied by two-dimensional gel electrophoresis of cell proteins. J Gen Microbiol 109, 259-263.

Salih, M. M., Simonsen, V. \& Ernø, H. (1983). Electrophoretic analysis of isoenzymes of Mycoplasma species. Acta Vet Scand 24, $14-33$.
Tryon, V. V. \& Baseman, J. B. (1992). Pathogenic determinants and mechanisms. In Mycoplasmas: Molecular Biology and Pathogenesis, pp. 457-471. Edited by J. Maniloff, R. N. McElhaney, L. R. Finch \& J. B. Baseman. Washington, DC: American Society for Microbiology.

Wadher, B. J. \& Miles, R. J. (1988). $\alpha$-Glucosidase in Mycoplasma mycoides subsp. capri. FEMS Microbiol Lett 49, 459-462.

Wadher, B. J., Varsani, H., Abu-Groun, E. A. \& Miles, R. J. (1990). Biochemical characterisation of bovine, caprine and ovine mycoplasmas. Abstracts of the 8th Congress of the International Organisation for Mycoplasmology (IOM), Istanbul, Turkey. IOM Lett 1, 517-518.

Received 2 September 1993; revised 14 January 1994; accepted 4 February 1994. 